\title{
Grain yield and aroma quality of upland rice (var. pare wangi) under various types and periods of drought stress
}

\author{
I G.B. ADWITA ARSA ${ }^{1, \boldsymbol{\nu}}$, ARIFFIN ${ }^{2}$, NURUL AINI' ${ }^{2}$, H.J.D. LALEL ${ }^{1}$ \\ ${ }^{1}$ Faculty of Agriculture, Universitas Nusa Cendana, Jl. Adisucipto, Penfui, Kupang 85148, East Nusa Tenggara, Indonesia. Tel./Fax. +62-380-881085, \\ remail: igbadwitaarsa@yahoo.com \\ ${ }^{2}$ Faculty of Agriculture, Universitas Brawijaya. Jl. Veteran, Malang 65145, East Java, Indonesia
}

Manuscript received: 1 March 2017. Revision accepted: 29 April 2017.

\begin{abstract}
Arsa IGBA, Ariffin, Aini N, Lalel HJD. 2017. Grain yield and aroma quality of upland rice (var. pare wangi) under various types and periods of drought stress. Trop Drylands 1: 17-23. Rice with unique aroma is often preferable and this trait can be achieved through exposing rice plants to drought and salinity stresses. Yet, particular rice varieties might respond differently to such stresses. The objective of this study was to evaluate the effect of type and period of drought stress on grain yield, physiological characters and aroma quality of aromatic Pare Wangi upland rice variety. Two-factor experiment was conducted in a greenhouse employing a Completely Randomized Design with three replications. The first factor was type of drought stress and the second factor was plant growth stage at which drought stress period was started. Observed data included yield components and grain yield pot ${ }^{-1}$, physiological characters, and aroma quality. Observed data were subjected to analysis of variance, HSD post hoc test, and simple correlation analysis. The research results indicated that the salinity stress effect of $2.0 \mathrm{~g} \mathrm{NaCl} \mathrm{kg} \mathrm{soil}^{-1}$ caused a higher percentage of unfilled grain as compared to that of other types of stresses. When the salinity stress was started at the booting stage, the chlorophyll content of the rice plants was lower than that of other stresses. Soil moisture stress of $75 \%$ FC that was started at booting stage produced the highest 2AP content and aroma quality. Proline content was not significantly correlated with 2AP content but it showed a positive correlation with grain yield pot ${ }^{-1}$.
\end{abstract}

Keywords: Upland rice, drought stress, aroma, proline, chlorophyll

Abbreviations: FC: Field Capacity, DAS: days after seeding, 2AP: 2-Acetil-1-Pyrroline, HSD: Honestly Significant Difference

\section{INTRODUCTION}

Crops are generally cultivated under optimum environmental conditions with minimal environmental stresses. Nonetheless, environmental stress is sometimes needed to obtain the desired traits. For example, it was reported that drought stress, to a certain extent, is useful to increase rice aroma quality of aromatic rice (Buttery et al. 1983; Yoshihashi 2005). This is the case for the aromatic Pare Wangi upland rice variety, a superior local upland rice variety that is now widely cultivated by farmers in South West Sumba District, East Nusa Tenggara Province, Indonesia. The local growers prefer Pare Wangi variety due to its taste and scent aroma, in addition to the higher selling price of the aromatic rice as compared to the non-aromatic ones.

The mechanism of the appearance of aroma in rice in relation to drought stress can be explained as follow. Drought stress results in the increase of various osmotic compounds (Bianco et al. 2000), one of which from nitrogen group is proline amino acid (Mohammadkhani and Heidari 2008). In non-aromatic rice, proline will change into glutamate acid whilst in the aromatic rice, biosynthesis process will produce 2-Acetil-1-Pyrrolin or 2AP (Kibria et al. 2008; Fitzgerald et al. 2010). The difference in biosynthesis is associated with a gene mutation in chromosome number 8 , exon 7 that is responsible for the missing of aldehyde-betaine-enzyme activity $\left(\mathrm{BADH}_{2}\right)$ (Bradbury 2009).

The increase of drought stress may be caused by a reduction in water supply from plant roots and excessive transpiration rate during the life cycle of the plant (Farooq et al. 2008, 2009). The reduction in water supply to the plant can be caused by a decrease in soil moisture and sometimes induced by an increase in soil salinity (Levitt 1980). For instance, Yoshihashi et al. (2004) reported the trial of Khao Dawk Mali 105 aromatic rice variety that found the 2AP content of rice planted on the sites with clay soil texture was lower (388 ppb) than that planted on sandy soil texture (518-528 ppb). Roychoudhury (2008) reported a significant increase of rice aroma quality in Gobindobhog variety that was subjected to salinity stresses compared to the control or without salinity treatment, and aroma quality of Gobindobhog variety was also higher than that of the non-aromatic rice variety.

In addition to drought stress, either because of the soil water deficit or the increase in soil salinity, the increase of 2AP content of aromatic rice plants may also be caused by soil nutrient factors such as Zn content (Jin-xia et al. 2009), P content (Rohilla et al. 2000), N content (Yang et al. 2012), and organic matter content (Champagne 2008; Islam and Sikder 2011). In general, it is reported that the balance of macro and micronutrients most significantly affects the increase of aroma quality of aromatic rice (Ram et al. 2013). 
The mechanisms of interaction between drought stress and nutrient balance factor in increasing the 2AP content of rice are not well understood until now. The negative correlation between aroma quality and productivity (Arsa et al. 2011; Yang et al. 2012) is possibly associated with the interaction of the above factors, implying that the increase in aroma quality is at the expense of the decrease in productivity. The lower level of drought stress will cause the amount of proline formed to be low enough to inhibit the nutrient uptake. On the other hand, high-level drought stress will induce a high amount of proline that may inhibit nutrient uptake. Thus, the amount of proline and the availability of nutrients in low or high-stress levels are not the optimum conditions for 2AP compound production. Therefore, it is necessary to determine the moderate level of drought stress for a maximum $2 \mathrm{AP}$ production. This can be done by arranging drought stress treatments; levels of soil moisture and or soil salinity and drought stress periods. Drought stress occurs during the phase of vegetative to harvest will give higher stress than that during the phase of reproductive or flowering to harvest. Differences in the length of drought stress period will affect the physiological processes of plants, which in turn affect the yield components and grain yield (Akram et al. 2013) and influence the aroma quality of rice.

Based on the above description, the objective of the present study was to evaluate the effect of drought stress by arranging the type and the length of drought stress period on grain yield, physiological characters, and aroma quality of the aromatic Pare Wangi upland rice variety.

\section{MATERIALS AND METHODS}

\section{Experimental design}

This study employed a Completely Randomized Design with a $3 \times 3$ factorial treatment design. The first factor was type of drought stress $(\mathrm{K})$, which consisted of 3 levels, i.e. soil moisture of $75 \%$ Field Capacity (FC) without $\mathrm{NaCl}$ (k1), soil moisture of $100 \% \mathrm{FC}$ and $2.0 \mathrm{~g} \mathrm{NaCl} \mathrm{kg} \mathrm{soil}^{-1}$ (k2), and soil moisture of $75 \% \mathrm{FC}$ and $1.0 \mathrm{~g} \mathrm{NaCl} \mathrm{kg} \mathrm{soil}^{-1}$ (k3). The second factor was drought stress period (F), which consisted of 3 levels, i.e. panicle initiation phase (at 60 DAS) (f1), booting phase (at 80 DAS) (f2), and panicle heading phase (at 100 DAS) (f3). A total of 9 treatment combinations were applied, each was 3 replicates. In total, 27 experimental units were included in the present study. Each experiment unit consisted of 2 planting pots (one pot for destructive and the other for non-destructive observations). Variables observed in this study included (i) yield component characters (number of panicles, number of grains (grains panicle ${ }^{-1}$ ), unfilled grains $(\%)$, weight of 100 grains (g), grain yield pot $^{-1}(\mathrm{~g})$ ), (ii) leaf tissue analysis, (iii) physiological characters (chlorophyll content and free proline content), and (iv) rice aroma quality (2AP content and aroma score).

\section{Preparation of media, planting, and fertilization}

Planting media used in the present study was soil taken from the area where the Pare Wangi upland rice variety has always been cultivated. The soil was first cleaned from plants debris and sieved with a $2.0 \mathrm{~mm}$ sieve size. Then, 7 $\mathrm{kg}$ of the sun-dried soil was filled into each planting pot. Each pot was then labeled and arranged in a greenhouse following the employed treatment design. Before planting, each pot was watered following the drought stress treatments with the amount of water given into the pot following the method of Wargadiputra and Harran (1983). Planting was done using five seeds per pot, and three healthy seedlings were retained two weeks after germination. The plants were maintained until harvest. Fertilizers were applied at planting time with, respectively, $250 \mathrm{~kg}$ Urea ha ${ }^{-1}\left(1.0 \mathrm{~g} \mathrm{Urea} \mathrm{pot}^{-1}\right), 100 \mathrm{~kg} \mathrm{SP} 6 \mathrm{ha}^{-1}(0.4 \mathrm{~g}$ SP36 pot $^{-1}$ and $200 \mathrm{~kg} \mathrm{KCl} \mathrm{ha}^{-1}\left(0.8 \mathrm{~g} \mathrm{KCl} \mathrm{pot}^{-1}\right)$. Weed was manually controlled throughout the experiment, while the pests were controlled by insecticide (Demolish 18 EC) spray once a week during flowering and grain filling stages.

\section{Treatment application}

The initial soil moisture for each pot was maintained at $100 \% \mathrm{FC}(\mathrm{w} / \mathrm{w})$, whereas drought stress treatments were given in a growth stage of the plant according to the assigned treatment. The addition of water to meet the drought stress treatment was given by gravimetric method. The $\mathrm{NaCl}$ was given according to the assigned treatment by dissolving the $\mathrm{NaCl}$ in water prior to its application to the growing media.

\section{Harvesting and grain sampling}

Harvesting was conducted when the panicles turned yellow and hardened. Harvest was done on the whole grain yields in non-destructive pots. The grain yields were then observed for yield components and grain yield per pot. Sufficient amount of grain was then used to test both rice 2AP content and organoleptic assay.

\section{Leaf tissue analysis}

Leaf tissue analysis was carried out at flowering stage (110 DAS). Two upper leaves (the second and the third leaf below the flag leaf) of each plant in destructive pot units were taken then were bulked for all replicates. A total of 9 composite leaf samples were produced which were then used to determine the leaf tissue contents of $\mathrm{N}, \mathrm{P}, \mathrm{K}, \mathrm{Na}$, and $\mathrm{Zn}$ by using Atomic Absorption Spectrophotometer (Perkin-Elmer 3110; J\&W Scientific, Folsom, CA, USA) following the standard method of AOAC (2000).

\section{Measurement of chlorophyll content}

Chlorophyll content was measured as follows: $2 \mathrm{~g}$ leaf sample was crushed with a mortar, and then added with 10 $\mathrm{ml}$ of $80 \%$ acetone. After that, the filtrate was poured through a funnel by a filter paper into a glass flask. The filtered filtrate was taken as many as $1 \mathrm{~mL}$, and then diluted to a volume of $10 \mathrm{~mL}$. This filtrate absorbance was measured by using a spectrophotometer. Total chlorophyll content was then calculated with the standard formula according to Arnon (1949), i.e. the sum of chlorophyll a and chlorophyll b. This procedure was applied to all leaf samples used to measure total chlorophyll content. The 
formula for calculation of chlorophyll-a $\left(\mathrm{mg} \mathrm{L}^{-1}\right)$ was= 12.70 x OD663-2.69 x OD645, while the chlorophyll-b $\left(\mathrm{mg} \mathrm{L}^{-1}\right)$ was $=22.9 \times$ OD645-4.68 $\times$ OD663.The unit was then converted into $\mathrm{mg} \mathrm{g}^{-1}$ fresh weight.

\section{Level of free proline}

The level of free proline (KPB) was determined following the procedure of Bates et al. (1973). A total of refined $0.5 \mathrm{~g}$ leaf sample was added with $10 \mathrm{~mL}$ of $3 \%$ $(\mathrm{v} / \mathrm{v})$ sulfosalisilic and then stirred. The filtrate was then filtered through a filter paper (Whatman No.40). Two mL of the filtrate were taken and reacted with $2 \mathrm{~mL}$ of acidic ninhydrin and $2 \mathrm{~mL}$ of glacial acetic acid. This process was carried out in a test tube at $100{ }^{\circ} \mathrm{C}$ for 1 hour and was then terminated by immersing the reaction tube in cold water (liquid ice). Proline extracts were obtained by adding $4 \mathrm{~mL}$ of toluene to the filtrate mixture for 15-20 seconds, and then stirred with a stirrer (stirrer test tube) and kept at room temperature to allow separation of toluene and water phases. Toluene phase absorbance was measured with a spectrophotometer at a wavelength of $520 \mathrm{~nm}$ (toluene was used as a blank). Total KPB was calculated by regression curve generated using the standard solutions.

\section{Measurement of 2AP content and aroma score}

The rice $2 \mathrm{AP}$ content was measured using composite samples of each treatment following the method of Lalel et al. (2003) and Wongpornchai et al. (2004). The volatile compounds were extracted using headspace solid-phase micro-extraction (HS-SPME) technique with the $100 \mu \mathrm{m}$ poly dimethyl siloxane SPME manual device (Supelco Co., Bellefonte, PA, USA). Separation and quantification of the 2AP compound were achieved using GC-MS (Hewlett Packard 5890 series, USA) equipped with a DB5MS capillary column $(50 \mathrm{~m} \mathrm{x} 0.2 \mathrm{~mm}$ id., $0.33 \mu \mathrm{m}$ film thickness; J \& W Scientific, Folsom, CA, USA). Total 2AP was calculated using external standard (calibration curve). The organoleptic assay was conducted by ten trained panelists to assess the rice aroma score following the modified method of Lestari et al. (2011). Rice was cooked in a test tube for 15 minutes and kept warm at $40^{\circ} \mathrm{C}$. Rice aroma quality was determined by scoring in a range of $0-4$ (no aroma to very strong aroma).

\section{Statistical analysis}

The observed data were subjected to analysis of variance (ANOVA) following a Completely Randomized Design approach. An HSD post hoc test at 5\% significance level was then conducted to compare the treatment means. Simple correlation analysis was also performed to examine the correlation between variables.

\section{RESULTS AND DISCUSSION}

\section{Yield components and grain yield}

Our research results revealed that type of drought stress treatment caused no significant effect on the number of panicles, number of grains, weight of 100 grains and grain yield per pot but the treatment significantly affected the percentage of unfilled grains. The drought stress induced by soil moisture of $100 \% \mathrm{FC}$ and $2.0 \mathrm{~g} \mathrm{NaCl} \mathrm{kg} \mathrm{soil}^{-1}(\mathrm{k} 2$ treatment) caused a significantly higher unfilled grain percentage than that of the other treatments. Furthermore, the effect of drought stress period started at booting phase (at 80 DAS) (f2 treatment) caused no significant effect on the observed variables except the 100-grain weight. Drought stress initiated at booting phase (f2) produced a significantly lower 100-grain weight than that started at panicle initiation phase (f1) and panicle heading phase (f3). Grain yield per pot did not differ among the treatments of drought stress period (Table 1).

\section{Chlorophyll and proline content}

Drought stress type induced by soil moisture of $75 \%$ Field Capacity (FC) without $\mathrm{NaCl}(\mathrm{k} 1)$ and soil moisture of $75 \% \mathrm{FC}$ and $1.0 \mathrm{~g} \mathrm{NaCl} \mathrm{kg} \mathrm{soil}^{-1}(\mathrm{k} 3)$ caused no significant effect on chlorophyll content, on the other hand, drought stress induced by soil moisture of $100 \% \mathrm{FC}$ and $2.0 \mathrm{~g} \mathrm{NaCl}$ $\mathrm{kg} \mathrm{soil}^{-1}(\mathrm{k} 2)$ started at booting phase (f2) produced a lower chlorophyll content as compared to that started at panicle initiation phase (f1) or panicle heading phase (f3) (Table 2). Furthermore, $\mathrm{k} 1$ treatment produced higher proline content than that of either $\mathrm{k} 2$ or $\mathrm{k} 3$ treatments, respectively. Drought stress type started at $\mathrm{f} 1$ stage also produced higher proline content as compared to that started at $\mathrm{f} 2$ and $\mathrm{f} 3$ (Table 2).

Table 1. Yield components and yield of Pare Wangi upland rice variety under various types and periods of drought stress

\begin{tabular}{|c|c|c|c|c|c|}
\hline \multirow{2}{*}{$\begin{array}{l}\text { Treatment } \\
(s)^{1)}\end{array}$} & \multicolumn{5}{|c|}{ Yield components and yield $^{2)}$} \\
\hline & NP & NG & UG & W100 & GY \\
\hline \multicolumn{6}{|c|}{$\begin{array}{l}\text { Drought stress } \\
\text { type }\end{array}$} \\
\hline $\mathrm{k} 1$ & $11.11 \mathrm{a}$ & $144.00 \mathrm{a}$ & $22.64 b$ & $2.29 \mathrm{a}$ & $29.01 \mathrm{a}^{3)}$ \\
\hline $\mathrm{k} 2$ & 1 & 162 & 32.8 & & \\
\hline $\mathrm{k} 3$ & & $7 \mathrm{a}$ & & & \\
\hline HSD 0.05 & 2.29 & 34.33 & 7.10 & 0.17 & 6.06 \\
\hline \multicolumn{6}{|c|}{$\begin{array}{l}\text { Drought stress } \\
\text { period }\end{array}$} \\
\hline f1 & 12. & & 28.1 & 2.4 & $29.21 \mathrm{a}$ \\
\hline $\mathrm{f} 2$ & & & & 2.2 & \\
\hline f3 & & 15 & 26. & $2.30 \mathrm{ab}$ & $28.31 \mathrm{a}$ \\
\hline HSD 0.05 & 2.29 & 34.33 & 7.10 & 0.17 & 6.06 \\
\hline \multicolumn{6}{|c|}{$\begin{array}{l}\text { Note: }{ }^{1)} \mathrm{k} 1 \text { : soil moisture of } 75 \% \mathrm{FC}+0 \mathrm{~g} \mathrm{NaCl} ; \mathrm{k} 2 \text { : soil moisture } \\
\text { of } 100 \% \mathrm{FC}+2.0 \mathrm{~g} \mathrm{NaCl} \mathrm{kg} \mathrm{soil}{ }^{-1} ; \mathrm{k} 3: \text { soil moisture of } 75 \% \mathrm{FC}+ \\
1.0 \mathrm{~g} \mathrm{NaCl} \mathrm{kg} \mathrm{soil-1} ; \mathrm{f} 1 \text { : drought stress initiated at } 60 \mathrm{DAS} ; \mathrm{f} 2 \text { : } \\
\text { drought stress initiated at } 80 \mathrm{DAS} \text {; and } \mathrm{f} 3 \text { : drought stress initiated } \\
\text { at } 100 \mathrm{DAS} \text {. }{ }^{2)} \mathrm{NP}: \text { number of panicles pot }{ }^{-1} \text {, NG: number of } \\
\left.\text { grains (grains panicle }{ }^{-1}\right) \text {, UG: unfilled grains }(\%) \text {, W100: weight } \\
\text { of } 100 \text { grains }(\mathrm{g}), \mathrm{GY} \text { : grain yield pot }{ }^{-1}(\mathrm{~g}){ }^{3)} \text { Numbers followed } \\
\text { by the same letter (s) are not significantly different at HSD post } \\
\text { hoc test }(0.05) \text {. }\end{array}$} \\
\hline
\end{tabular}


Table 2. Chlorophyll and proline content of Pare Wangi upland rice variety under various types and periods of drought stress

\begin{tabular}{|c|c|c|c|c|c|c|c|c|}
\hline \multirow{2}{*}{ Treatment $^{1)}$} & \multicolumn{3}{|c|}{ Chlorophyll (mg g BS $\left.{ }^{-1}\right)$} & \multirow{2}{*}{ Average } & \multicolumn{3}{|c|}{ Proline $\left(\mu \mathrm{mol} \mathrm{g} \mathrm{BS}^{-1}\right)$} & \multirow[b]{2}{*}{ Average } \\
\hline & f1 & f2 & f3 & & f1 & f2 & f3 & \\
\hline \multirow[t]{2}{*}{ k1 } & $1.29 \mathrm{a}$ & $1.37 \mathrm{a}$ & $1.15 \mathrm{a}$ & 1.27 & 15.60 & 14.91 & 14.21 & 14.91 \\
\hline & A & $\mathrm{AB}$ & $\mathrm{A}$ & & & & & $A^{2)}$ \\
\hline \multirow[t]{2}{*}{$\mathrm{k} 2$} & $1.43 \mathrm{a}$ & $1.12 \mathrm{~b}$ & $1.34 \mathrm{ab}$ & 1.30 & 14.88 & 14.32 & 14.47 & 14.56 \\
\hline & A & B & A & & & & & $\mathrm{AB}$ \\
\hline \multirow[t]{2}{*}{$\mathrm{k} 3$} & $1.30 \mathrm{a}$ & $1.41 \mathrm{a}$ & $1.25 \mathrm{a}$ & 1.32 & 14.38 & 13.85 & 14.23 & 14.15 \\
\hline & A & A & A & & & & & B \\
\hline Average & 1.34 & 1.30 & 1.25 & 1.30 & $14.95 \mathrm{a}$ & $14.36 \mathrm{~b}$ & $14.30 \mathrm{~b}$ & 14.54 \\
\hline
\end{tabular}

Note: ${ }^{1)} \mathrm{k} 1$ : soil moisture of $75 \% \mathrm{FC}+0 \mathrm{~g} \mathrm{NaCl}$; $\mathrm{k} 2$ : soil moisture of $100 \% \mathrm{FC}+2.0 \mathrm{~g} \mathrm{NaCl} \mathrm{kg} \mathrm{soil}{ }^{-1} ; \mathrm{k} 3$ : soil moisture of $75 \% \mathrm{FC}+$ $1.0 \mathrm{~g} \mathrm{NaCl} \mathrm{kg} \mathrm{soil}^{-1}$; f1: drought stress initiated at $60 \mathrm{DAS}$; f2: drought stress initiated at $80 \mathrm{DAS}$; and f3: drought stress initiated at 100 DAS. ${ }^{2)}$ Means followed by the same letter (s) are not significantly different at HSD post hoc test (0.05) (small letter shows comparisons in the same row and capital letter shows comparisons in the same column)

\section{Content of 2AP, aroma score, and leaf tissue nutrient}

We found in the present study that the highest $2 \mathrm{AP}$ content of rice induced by drought stress type due to soil moisture content of $75 \% \mathrm{FC}+0 \mathrm{~g} \mathrm{NaCl}(\mathrm{k} 1)$ was produced when the stress was applied at booting phase (f2) while drought stress type induced by soil moisture of $100 \% \mathrm{FC}+$ $2.0 \mathrm{~g} \mathrm{NaCl} \mathrm{kg} \mathrm{soil}^{-1}(\mathrm{k} 2)$ and soil moisture of $75 \% \mathrm{FC}+1.0$ g NaCl kg soil ${ }^{-1}(\mathrm{k} 3)$, respectively, produced the highest 2AP content when these treatments were initiated at panicle heading phase (f3). The $\mathrm{k} 1$ treatment applied at $\mathrm{f} 2$ stage apparently produced the highest $2 \mathrm{AP}$ content $(3.07 \mathrm{ppb})$ (Table 3). Aroma scores of rice determined through organoleptic test fell in the range of 1.7 to 2.2. The drought stress type of $\mathrm{k} 1$ treatment applied at $\mathrm{f} 2$ stage showed the highest rice aroma score and that of $\mathrm{k} 2$ treatment applied at panicle initiation phase (f1) showed the lowest one. The range of aroma scores produced by either $\mathrm{k} 1$ treatment or k3 treatment was relatively higher than that of $\mathrm{k} 2$ treatment. These findings showed that drought stress caused by water deficit or its combination with salinity application was stronger than the salinity application alone (without water deficit) in increasing the rice aroma (Table $3)$.

The effect of the single treatment drought stress type $(\mathrm{K})$ and drought stress period $(\mathrm{F})$ on the leaf tissue contents of $\mathrm{Na}, \mathrm{N}, \mathrm{P}, \mathrm{K}$, and $\mathrm{Zn}$ are presented in Table 4 . Na content of leaf tissue treated with $\mathrm{k} 2$ (soil moisture of $100 \% \mathrm{FC}+$ $2.0 \mathrm{~g} \mathrm{NaCl} \mathrm{kg} \mathrm{soil}^{-1}$ ) was higher than that of either $\mathrm{k} 1$ (soil moisture of $75 \% \mathrm{FC}+0 \mathrm{~g} \mathrm{NaCl}$ ) or $\mathrm{k} 3$ (soil moisture of $75 \% \mathrm{FC}+1.0 \mathrm{~g} \mathrm{NaCl} \mathrm{kg} \mathrm{soil-}{ }^{1}$ ) over all periods of drought stress. Effect of $\mathrm{k} 3$ treatment tended to increase the leaf tissue $\mathrm{Na}$ content as compared to $\mathrm{k} 1$ treatment but there was no significant effect of drought stress type and period on leaf tissue contents of $\mathrm{N}, \mathrm{P}, \mathrm{K}$, and $\mathrm{Zn}$.

\section{Correlation between plant characters}

Results of correlation analysis between yield components showed that number of grains (grain panicle ${ }^{-1}$ ) was negatively correlated with number of panicles but there was no correlation between 100-grain weight and number of grains. The correlation analysis also revealed that none of the observed yield components was correlated with grain yield pot $^{-1}$ (Table 5). The present study results also showed that $\mathrm{N}$ content has no correlation with either each of the yield components or the grain yield pot $^{-1}$. Similarly, no correlation was observed between $\mathrm{Na}$ content of leaf tissue and each of the following characters, respectively: yield components, grain yield pot $^{-1}$, and $\mathrm{Na}$ content. Furthermore, chlorophyll content showed only positive correlation with 100-grain weight while proline content apparently has a positive correlation with grain yield pot $^{-1}$ but it was not correlated with rice $2 \mathrm{AP}$ content (Table 5).

Table 3. $2 \mathrm{AP}$ and aroma score of Pare Wangi upland rice variety under various types and periods of drought stress

\begin{tabular}{lcccccc}
\hline \multirow{2}{*}{ Treatment $^{1)}$} & \multicolumn{3}{c}{ 2AP $(\mathbf{p p b})+$} & \multicolumn{3}{c}{ Aroma Score + } \\
\cline { 2 - 7 } & $\mathbf{f 1}$ & $\mathbf{f 2}$ & $\mathbf{f 3}$ & $\mathbf{f 1}$ & $\mathbf{f 2}$ & $\mathbf{f 3}$ \\
\hline $\mathrm{k} 1$ & 2.92 & 3.07 & 2.45 & 2.0 & 2.2 & 2.1 \\
$\mathrm{k} 2$ & 2.36 & 2.01 & 2.65 & 1.7 & 1.8 & 1.9 \\
$\mathrm{k} 3$ & 2.30 & 2.33 & 2.71 & 2.0 & 2.0 & 2.1 \\
\hline
\end{tabular}

Note: ${ }^{1)} \mathrm{k} 1$ : soil moisture of $75 \% \mathrm{FC}+0 \mathrm{~g} \mathrm{NaCl}$; $\mathrm{k} 2$ : soil moisture of $100 \% \mathrm{FC}+2.0 \mathrm{~g} \mathrm{NaCl} \mathrm{kg} \mathrm{soil}^{-1} ; \mathrm{k} 3$ : soil moisture of $75 \% \mathrm{FC}+$ $1.0 \mathrm{~g} \mathrm{NaCl} \mathrm{kg} \mathrm{soil-}{ }^{1} ; \mathrm{f} 1$ : drought stress initiated at $60 \mathrm{DAS} ; \mathrm{f} 2$ : drought stress initiated at $80 \mathrm{DAS}$; and f3: drought stress initiated at $100 \mathrm{DAS} ;+$ : data was not subjected ANOVA

Table 4. Content of $\mathrm{Na}, \mathrm{N}, \mathrm{P}, \mathrm{K}$ and $\mathrm{Zn}$ in leaf tissues of Pare Wangi upland rice variety under various types and periods of drought stress

\begin{tabular}{lccccc}
\hline & \multicolumn{5}{c}{ Content in leaf tissues } \\
\cline { 2 - 6 } Treatment (s) ${ }^{\mathbf{1})}$ & $\begin{array}{c}\mathbf{N a} \\
(\boldsymbol{\%})\end{array}$ & $\mathbf{N}(\boldsymbol{\%})$ & $\mathbf{P}(\boldsymbol{\%})$ & $\mathbf{K}(\boldsymbol{\%})$ & $\begin{array}{c}\mathbf{Z n} \\
(\mathbf{p p m})\end{array}$ \\
\hline $\begin{array}{l}\text { Drought stress } \\
\text { type }\end{array}$ & & & & & \\
k1 & 0.79 & 2.19 & 0.83 & 1.48 & 81.16 \\
k2 & 1.17 & 2.19 & 0.87 & 1.49 & 80.51 \\
k3 & 0.91 & 2.24 & 0.82 & 1.55 & 80.60
\end{tabular}

Drought stress period

\begin{tabular}{llllll} 
f1 & 0.92 & 2.19 & 0.82 & 1.51 & 80.58 \\
f2 & 0.95 & 2.29 & 0.86 & 1.48 & 81.11 \\
f3 & 1.00 & 2.14 & 0.85 & 1.54 & 80.57 \\
\hline
\end{tabular}

Note: ${ }^{1)} \mathrm{k} 1$ : soil moisture of $75 \% \mathrm{FC}+0 \mathrm{~g} \mathrm{NaCl} ; \mathrm{k} 2$ : soil moisture of $100 \% \mathrm{FC}+2.0 \mathrm{~g} \mathrm{NaCl} \mathrm{kg} \mathrm{soil}{ }^{-1} ; \mathrm{k} 3$ : soil moisture of $75 \% \mathrm{FC}+$ $1.0 \mathrm{~g} \mathrm{NaCl} \mathrm{kg} \mathrm{soil-}{ }^{1} ; \mathrm{f} 1$ : drought stress initiated at $60 \mathrm{DAS} ; \mathrm{f} 2$ : drought stress initiated at $80 \mathrm{DAS}$; and f3: drought stress initiated at $100 \mathrm{DAS}$ 
Table 5. Results of simple correlation analysis between observed variables

\begin{tabular}{llllllllll}
\hline Variable & JG & W100 & GY & N $(\%)$ & Na $(\%)$ & Klo & Pro & 2AP & Aroma \\
\hline NP & $-0.63^{* *}$ & $0.55 \mathrm{~ns}$ & $-0.31 \mathrm{~ns}$ & $-0.54 \mathrm{~ns}$ & $0.46 \mathrm{~ns}$ & $0.21 \mathrm{~ns}$ & $-0.10 \mathrm{~ns}$ & $-0.11 \mathrm{~ns}$ & $-0.29 \mathrm{~ns}$ \\
NG & & $-0.34 \mathrm{~ns}$ & $0.14 \mathrm{~ns}$ & $0.46 \mathrm{~ns}$ & $0.18 \mathrm{~ns}$ & $-0.18 \mathrm{~ns}$ & $-0.22 \mathrm{~ns}$ & $-0.36 \mathrm{~ns}$ & $-0.24 \mathrm{~ns}$ \\
W100 & & & $0.50 \mathrm{~ns}$ & $-0.02 \mathrm{~ns}$ & $-0.09 \mathrm{~ns}$ & $0.70 *$ & $0.36 \mathrm{~ns}$ & $0.30 \mathrm{~ns}$ & $-0.08 \mathrm{~ns}$ \\
GY & & & & $0.19 \mathrm{~ns}$ & $-0.56 \mathrm{~ns}$ & $0.26 \mathrm{~ns}$ & $0.73^{*}$ & $0.59 \mathrm{~ns}$ & $0.22 \mathrm{~ns}$ \\
N $(\%)$ & & & & & $-0.18 \mathrm{~ns}$ & $0.60 \mathrm{~ns}$ & $0.03 \mathrm{~ns}$ & $0.23 \mathrm{~ns}$ & $0.12 \mathrm{~ns}$ \\
Na (\%) & & & & & & $-0.08 \mathrm{~ns}$ & $-0.35 \mathrm{~ns}$ & $-0.65 *$ & $-0.83 * *$ \\
Chlo & & & & & & & $0.20 \mathrm{~ns}$ & $0.31 \mathrm{~ns}$ & $-0.04 \mathrm{~ns}$ \\
Pro & & & & & & & $0.59 \mathrm{~ns}$ & $-0.03 \mathrm{~ns}$ \\
2AP & & & & & & & & & \\
\hline
\end{tabular}

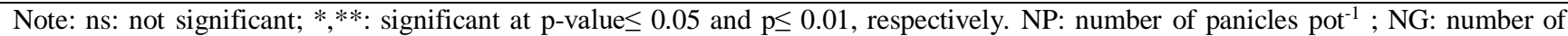
grains (grains panicle ${ }^{-1}$ ); W100: weight of 100 grains (g); GY: grain yield pot ${ }^{-1}$ (g); Chlo: Chlorophyll content (mgg BS ${ }^{-1}$ ); Pro: Prolin content $\left(\mu \mathrm{mol} \mathrm{g} \mathrm{BS}{ }^{-1}\right)$; $2 \mathrm{AP}: 2 \mathrm{AP}$ content (ppb), Aroma: Aroma score

\section{Discussion}

Number of unfilled grains under the drought stress type of $\mathrm{k} 2$ treatment $\left(2.0 \mathrm{~g} \mathrm{NaCl} \mathrm{kg} \mathrm{soil}{ }^{-1}\right)$ was higher than that of either $\mathrm{k} 1$ treatment $(75 \% \mathrm{FC}$ and $0 \mathrm{~g} \mathrm{NaCl})$ or $\mathrm{k} 3$ treatment (75\% FC and $1.0 \mathrm{~g} \mathrm{NaCl} \mathrm{kg} \mathrm{soil}^{-1}$ ) (Table 1). This indicated a higher seed abortion rate under the $\mathrm{k} 2$ treatment as compared to either $\mathrm{k} 1$ or $\mathrm{k} 3$ treatments. The enhancement of $\mathrm{Na}$ uptake in $\mathrm{k} 2$ treatment (Table 4) showed a tendency of positive correlation with number of panicles but number of panicles has a negative correlation with number of grains, which caused $\mathrm{Na}$ content of leaf tissue has a negative correlation with grain yield pot $^{-1}$ (Table 5). These findings indicated that $\mathrm{k} 2$ treatment affected the photosynthesis process, which hereinafter affected carbohydrate formation and its translocation to the seeds. In the end, lack of carbohydrates caused more seeds not to be fully formed or to become unfilled grains (Jaleel et al. 2009).

Drought stress that was started at $\mathrm{f} 2$ stage (80 DAS) caused the plant to produce a lower 100-grain weight compared to that at $\mathrm{f} 1$ stage (60 DAS) but it was not significantly different from that at $\mathrm{f} 3$ stage (100 DAS) (Table 1). This implies that the supply of carbohydrates from leaves to the seeds was more significantly reduced when the drought stress was started at $\mathrm{f} 2$ than at $\mathrm{f} 1$. Plants that revived drought stress treatment at $\mathrm{f} 2$ stage exhibited leaf chlorosis symptoms and the leaves were then dried out. The symptom was mainly related to the influence of $k 2 \mathrm{f} 2$ treatment that significantly reduced leaf chlorophyll content as compared to k1f2 and k3f2 treatments (Table 2). The decrease in leaf chlorophyll content affected the effectiveness of the photosynthesis process, which in turn reduced the amount of carbohydrates translocated to the seeds.

The tendency of the decrease in leaf chlorophyll content of the plants treated with drought stress types $\mathrm{k} 1$ and $\mathrm{k} 3$ at the drought stress period $\mathrm{f3}$ (Table 2) was presumably caused by the plant's adjustment mechanisms. At the drought stress treatment period $\mathrm{f} 3$, the plants grew without drought stress in the vegetative stage but were then subjected to drought stress in the generative stage, especially close to the flowering stage when the plants' water consumption increased significantly. One of the plant's adjustment mechanisms in facing such situation was by reducing new chlorophyll formation, and otherwise by increasing chlorophyll molecule degradation. As a result, the decreased leaf chlorophyll content of plants treated with $\mathrm{k} 2$ drought stress type at $\mathrm{f} 2$ might be related to the increase of leaf tissue Na content (Table 4) triggered by the increase of transpiration process. Visually, this process caused the older thick leaf to be drying out.

Observed rice 2AP content and aroma score presented in Table 3 indicated that the range of $2 \mathrm{AP}$ content of plants treated with drought stress type $\mathrm{k} 1$ was higher than that of other treatments, either $\mathrm{k} 2$ or $\mathrm{k} 3$. This might have been caused by the increase of salinity that affected the biosynthesis of proline to become 2AP compound. At the drought stress type $\mathrm{k} 1$, it was likely that more proline was used to form 2AP compound as compared to that of $\mathrm{k} 2$ and $\mathrm{k} 3$. Meanwhile, at the drought stress types $\mathrm{k} 2$ and $\mathrm{k} 3$, the formation of proline might be more useful as an osmoprotectant than as a precursor of 2AP compound. This was mainly seen in the drought stress types started at f1 and $\mathrm{f} 2$ stages, where lower 2AP contents were produced compared to that at $\mathrm{f} 3$. On the contrary, the drought stress type $\mathrm{k} 1$ started at $\mathrm{f} 3$ stage was also likely to reduce proline content (as a precursor of 2AP compound), so that the 2AP content at this treatment was lower than that of $\mathrm{k} 1$ started at either f1 or f2 stages (Table 3). Gay et al. (2010) reported that the formation of rice $2 \mathrm{AP}$ compound was predicted to occur before heading phase; meanwhile, Itaniet et al. (2004) found that the highest 2AP content was reached at 4-5 weeks after heading phase. Therefore, the different treatments of drought stress levels and starting periods applied in this study presumably determined the observed difference in time (phase) for the highest rice-2AP production we found in the present study.

Grain yield pot $^{-1}$ was positively correlated with 100seed weight, meanwhile, number of panicles plant ${ }^{-1}$ and number of grains panicle ${ }^{-1}$ showed a negative correlation (Table 4), and consequently, these two yield components have no contribution to grain yield pot $^{-1}$. Grain yield pot $^{-1}$ was mainly determined by 100 -seed weight that was positively correlated with number of panicles. Shahidullah et al. (2009) reported that in aromatic rice, number of panicles was positively correlated with grain yield but its 
effect has frequently occurred indirectly through other characters such as 100-seed weight and number of grains panicle ${ }^{-1}$

There was no correlation between grain yield pot $^{-1}$ and leaf tissue $\mathrm{N}$ content, which may likely be related to the observed negative correlation between leaf tissue $\mathrm{N}$ content and number of panicles, and on the other side, there was a positive correlation between leaf tissue $\mathrm{N}$ content and number of grains panicle ${ }^{-1}$. It was also revealed in the present study that there was no correlation between $\mathrm{Na}$ content and grain yield pot $^{-1}$. The non-significant positive correlation between leaf tissue $\mathrm{Na}$ content and number of panicles, in addition to the negative correlation between number of panicles and number of grains, maybe the causal factor of the non-significant negative correlation between leaf tissue $\mathrm{Na}$ content and the grain yield pot $^{-1}$ (Table 5).

The observed positive correlation between rice $2 \mathrm{AP}$ content and grain yield pot $^{-1}$ (Table 5) shows that the increase of rice $2 \mathrm{AP}$ content will be followed by the increase of grain yield pot $^{-1}$ if the plants were exposed to a moderate level of drought stress after generative phase. This phenomenon was likely to involve endogen proline activity. The significant positive correlation observed between proline and grain yield pot $^{-1}$ was also supported by the tendency of a positive correlation between the leaf tissue proline content and the rice $2 \mathrm{AP}$ content. Thus, there is a tendency for a positive correlation between rice $2 \mathrm{AP}$ content and grain yield $\operatorname{pot}^{-1}$. The positive correlation between proline content and rice 2AP content observed in the present study demonstrates that Pare Wangi rice variety has experienced a moderate level of drought stress. In contrast to this finding, previous studies (Kibria et al. 2008; Yang et al. 2012) reported that 2AP content of rice was negatively correlated with grain yield.

Based on the results of the present study, the following conclusions are made: (i) The treatment interaction of type and period of drought stress did not affect the grain yield pot $^{-1}$ but affected both leaf tissue chlorophyll content and rice 2AP-compound content. (ii) The main effect of drought stress type separately affected the percentage of unfilled grains, and the drought stress period affected the 100-grain weight. (iii) The percentage of unfilled grains

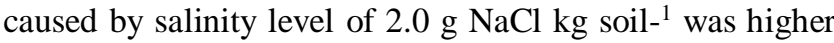
than that caused by soil moisture of $75 \% \mathrm{FC}$ and the combination of the treatments (soil moisture of $75 \%$ FC

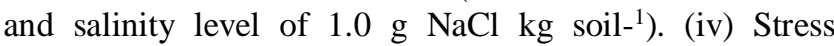
treatment of salinity level of $2.0 \mathrm{~g} \mathrm{NaCl} \mathrm{kg}$ soil- ${ }^{1}$ started at booting stage (80 DAS) produced lower chlorophyll content as compared to other treatments. (v) Drought stress type of soil moisture of $75 \%$ FC started at booting stage produced the highest rice $2 \mathrm{AP}$-compound content and aroma score. (vi) Proline content of leaf tissue has no correlation with rice $2 \mathrm{AP}$ - compound content but it has a positive correlation with grain yield pot $^{-1}$.

\section{ACKNOWLEDGEMENTS}

The authors would like to thank Agustinus Wakur for his assistance, especially during the research activities in the field.

\section{REFERENCES}

Akram HM, Ali A, Sattar A, Rehman HSU, Bibi A. 2013. Impact of water deficit stress on various physiological and agronomic traits of three Basmati rice (Oryza sativa L.) cultivars. J Anim Plant Sci 23 (5): 1415-1423.

AOAC. 2000. Official Methods of Analysis. 17th edition. Official Methods 935.35. Ed. by the Association of Official Analytical Chemists, Maryland, U.S.A.

Arnon DI. 1949. Copper enzymes in isolated chloroplasts polyphenol oxidase in Beta vulgaris. Plant Physiol 24: 1-15. DOI: 10.1104/pp.24.1.1

Arsa, IGBA, Lalel HJD, Adu Tae ASJ. 2011. Study of determining factors in productivity and quality of aromatic Pare Wangi rice in dryland of East Nusa Tenggara. Research Grant from High Education Directorate, Cultural and Education Ministry of Indonesia. [Indonesian]

Bates LS, Waldren RP, Teare ID. 1973. Rapid determination of free proline for water stress studies. Plant Soil 39: 205-208. DOI: 10.1007/BF00018060

Bianco RL, Rieger M, Sung S S. 2000. Effect of drought on sorbitol and sucrose metabolism in sinks and sources of peach. Physiol Plant 108: 71-78. DOI: 10.1034/j.1399-3054.2000.108001071.x

Bradbury LMT. 2009. Identification of the gene responsible for fragrance in rice and characterisation of the enzyme transcribed from this gene and its homologs. [Thesis]. ePublications@SCU. Southern Cross University, Lismore, NSW.

Buttery RG, Ling LC, Bienvenido, Juliano, Turnbaugh JG. 1983. Cooked rice aroma and 2-Acetyl-1-Pyrroline. J Agric Food Chem 3 (1): 23 828. DOI: $10.1021 / \mathrm{jf00118a036}$

Champagne ET. 2008. Rice aroma and flavor: A literature review. Cereal Chem 85 (4): 445-454. DOI: 10.1094/CCHEM-85-4-0445

Farooq M, Basra SMA, Wahid A, Cheema ZA, Cheema MA, Khaliq A. 2008. Physiological role of exogenously applied glycinebetaine to improve drought tolerance in fine grain aromatic rice (Oryza sativa L.). J Agron Crop Sci 194 (5): 325-333. DOI: 10.1111/j.1439037X.2008.00323.X

Farooq M, Basra SMA, Wahid A, Ahmad N, Saleem BA. 2009. Improving the drought tolerance in rice (Oryza sativa L.) by exogenous application of salicylic acid. J Agron Crop Sci 195 (4): 237-246. DOI: 10.1111/j.1439-037X.2009.00365.x

Fitzgerald, TL, Ean Waters DL, Brooks LO, Henry RJ. 2010. Fragrance in rice (Oryza sativa) is associated with reduced yield under salt treatment. Environ Exp Bot 68: 292-300. DOI: 10.1016/j.envexpbot.2010.01.001

Gay F, Maraval I, Roques S, Gunata Z, Boulanger R, Audebert A, Mestres C. 2010. Effect of salinity on yield and 2-acetyl-1-pyrroline content on the grains of three fragrant rice cultivars (Oryza sativa L.) in Camargue (France). Field Crops Res 117: 154-160. DOI: 10.1016/j.fcr.2010.02.008

Islam MR, Sikder S. 2011. Phenology and degree days of rice cultivars under organic culture. Bangladesh J Bot 40 (2): 149-153. DOI: 10.3329/bjb.v40i2.9770

Jin-xia H, Xiao Di, Yang DM, Hua T, Guo-xi L, Ke-you Z, Xiang-ru T. 2009. Effects of Different Applications of $\mathrm{ZnCl}_{2}$ on the Yield and Aroma Content of Aromatic Rice. College of Agronomy, South China Agricultural University, Guangzhou 510642, China.

Kibria K, Islam MM, Begum SN. 2008. Screening of aromatic rice lines by phenotypic and molecular markers. Bangladesh J Bot 37 (2): 141147. DOI: $10.3329 /$ bjb.v37i2.1720

Lalel HJD, Singh Z, Tan SC. 2003. Aroma volatiles production during fruit ripening of 'Kensington Pride' mango. Postharvest Biol Technol 27: 323-336. DOI: 10.1016/S0925-5214(02)00117-5

Lestari AP, Abdullah B, Junaedi A, Aswidinnoor H. 2011. Performance of grain quality and aroma of new plant type promising aromatic rice 
lines. Indon J Agric Sci 12 (2): 84-93. DOI: 10.21082/ijas.v12n2.2011.p83-93

Levitt J. 1980. Responses of Plants to Environmental Stresses. Vol II Water Radiation, Salt and Other Stresses. Academic Press, New York.

Mohammadkhani N, Heidari R. 2008. Drought-induced accumulation of soluble sugars and proline in two maize varieties. World Appl Sci J 3 (3): 448-453

Ram US, Srivatasva VK, Hemantaranjan A, Sen A, Singh RK, Bohra JS, Shukla U. 2013. Effect of Zn, Fe, and FYM application on growth, yield, and nutrient content of rice. Oryza 50 (4): 351-357.

Rohilla R, Singh VP, Singh US, Singh RK, Khush GS. 2000. Crop Husbandry and Environmental Factors Affecting Aroma and Other Quality Traits. In: Singh RK, Singh US, Khush GS (Eds). Aromatic Rice. Oxford \& IBH Publishing Co. Pvt. Ltd., New Delhi.

Roychoudhury A, Basu S, Sarkar SN, Sengupta DN. 2008. Comparative physiological and molecular responses of a common aromatic indica rice cultivar to high salinity with non-aromatic indica rice cultivars. Plant Cell Rep 27: 1395-1410. DOI: 10.1007/s00299-008-0556-3
Shahidullah SM, Hanafi MM, Ashrafuzzaman M, Ismail MR, Salam MA. 2009. Tillering Dynamics in Aromatic Rice Genotypes. Intl J Agric Biol 11 (5): 509-514.

Wargadiputra R, Harran S. 1983. Effect of soil water retention on growth and yield of stevia from stem cuttings and seeds. Bul Agr 15 (1\&2): 40-56. [Indonesian]

Wongpornchai S, Dumri K, Jongkaewwattana S, Siri B. 2004. Effects of drying methods and storage time on the aroma and milling quality of rice (Oryza sativa L.) cv. Khao Dawk Mali 105. Food Chem 87: 407414. DOI: 10.1016/j.foodchem.2003.12.014

Yang S, Zou Y, Liang Y, Xia B, Liu S, Ibrahim Md, Li D, Li Y, Chen L, Zeng Y, Liu L, Chen Y, Li P, Zhu J. 2012. Role of soil total nitrogen in aroma synthesis of traditional regional aromatic rice in China. Field Crops Res 125: 151-160. DOI: 10.1016/j.fcr.2011.09.002

Yoshihashi T, Nguyen TTH, Kabaiki N, 2004. Area dependency of 2Acetyl-1-Pyrroline content in an aromatic rice variety, Khao Dawk Mali 105. Jarq 38 (2): 105-109. DOI: 10.6090/jarq.38.105

Yoshihashi T. 2005. Does drought condition induce the aroma quality of aromatic rice? Food Science and Technology Division, JIRCAS. JIRCAS Newsletter No.43, June 2005. 